\title{
Tai Lue Traditions in a Transnational World: Study of Tai Lue Community in the United States of America
}

\author{
Nanshan KANG \\ Yunnan Buddhist College, Kunming, China
}

\begin{abstract}
Historical political movements and wars forced the Tai Lue to escape from their hometown and finally, they migrated to the United States. There are too many sorrowful stories of their escaping from China to Myanmar, Laos, Thailand, and new-coming to the USA. The skills for work, working environments and working time are all different from what they had done in Asia. They realize that it is important for them to preserve their traditional culture in the USA. One the one hand, keeping their traditional culture could make them safe, and on the other hand, make them happy and help them reduce homesickness. Theravada Buddhism is their main traditional culture. When the Tai Lue move to the USA, they have to negotiate the mainstream culture and modify their behaviors in order to maintain their traditions as much as possible. The US circumstances provide Tai Lue Americans with both negatives and positives for preserving their traditions. The cultural freedom in the USA provides the Tai Lue the freedom to maintain their traditional culture but some aspects also conflict with American laws and regulations. American Western culture also influences their traditions. Globalization not only provides the Tai Lue traditional culture with possible and similar conditions to extend in the USA, but also helps Tai Lue Americans to do their contributions to the traditions in their motherland. The identity of the Tai Lue is misunderstood as the Lao by the public. Tai Lue Americans are still moving and working for their lives, and they are contemporarily keeping their tradition in the USA. However, it will be hard for Tai Lue American elders to transfer the traditions to their next generation.
\end{abstract}

Keywords: political movement, immigration, Buddhism, tradition, modification

\section{Introduction}

Tai Lue people residing in the United States of America (USA) — known as "Tai Lue Americans" - have not been recognized publicly nor by the US government. The Tai Lue is an ethnic group from southwestern China and northern Laos, and in the USA it numbers around 4,500 people from about 1,000 families. Tai Lue Americans live in places as geographically dispersed as Colorado, Kansas, Illinois, California, Arizona, Texas, Arkansas, Connecticut and Indiana, and a few other states, and they migrated to the USA between 1979 and 1994. They originally lived in SipsongPanna, Yunnan Province in China, but escaped to Laos during China's "Great Leap Forward" period (1958-1959) and during the "Great Proletarian Cultural Revolution" (1966-1976). Having moved to Laos during the Lao Civil Wars (1962-1975), they then fled to Thailand and again became refugees, after which the United Nations and the US government helped them to migrate to the USA. In this

\footnotetext{
Nanshan KANG, Vice-President, Yunnan Buddhist College; Vice Secretary-General, The Buddhist Association of Yunnan Province.
} 
chapter, I will argue that Tai Lue Americans have managed to preserve their traditional culture and customs despite the situation they have found themselves inside the USA. I will describe the relationship that Tai Lue Americans have with their hometowns in China, and the traumas they experienced in China, Laos and Thailand while fleeing persecution. I will also reveal that the Tai Lue's traditional culture and customs have been modified since they arrived in the USA.

As a Tai Lue person myself, I have been interested in the Tai Lue living in the USA since early 2003, when I visited a number of them, along with the Abbot of Wat Pajay (Zongfo temple) (the central Buddhist temple in Sipsong Panna), the Venerable Khuba Longjorm in California, Colorado and Illinois in February and March. During these visits, I was greatly interested in which aspects of traditional Tai Lue culture they still practiced in the USA, and I also heard about the trauma they experienced during the "Great Leap Forward" and the "Cultural Revolution" periods in China, the Laotian Civil War in Laos, and then in the refugee camps in Thailand from the late 1970s to the early 1990s. When I went back to Yunnan, China and told my friends there were many Tai Lue people in the USA, they were surprised to hear it; they could not imagine that Tai Lue people in SipsongPanna would have had the ability to emigrate to the USA. Up until today, the government in SipsongPanna has not paid much attention to or cared about the issue of the Tai Lue who left SipsongPanna during that time. The country marked on their identity cards in the USA says "Laos", and the US government regards them as Laotians, because they registered as Laotian refugees when they resided in the refugee camps in northern Thailand.

The Tai Lue are a part of the Tai ethno-linguistic community which is scattered throughout Southeast Asia, and Tai Lue Americans can be divided into four groups: the Tai Lue, Tai Neua, Tai Yai (Shan) and Tai Dam (or Tai Dum). The similarities and differences in their customs are a consequence of the original customs adopted by the different groups in Asia. For the Tai Lue, Tai Neua and Tai Yai, their spoken language is the same but their written languages are different. The Tai Lue, Tai Neua and Tai Yai all follow Theravada Buddhism, but the Tai Dam do not. This paper focuses primarily on Tai Lue Americans and also considers Tai Neua and Tai Yai Americans to the extent that their behaviors and circumstances are similar. The population of Tai Neua and Tai Yai Americans are much smaller than those of the Tai Lue, and there are only about 40 Tai Neua American families, most of who live in Rockford, Illinois, where they have a Buddhist temple. The Tai Neua and Tai Yai practice Theravada Buddhist in the same way as the Tai Lue, but the Tai Yai Americans do not have a Buddhist temple. Tai Neua traditional culture is very much like the Tai Lue's, and Tai Neua Americans can still trace their relatives to Jinggu County in Simao, China, though none of them were born there-it was their grandparents who migrated from Jinggu to Muang Sing in Laos initially. Tai Yai (Shan) Americans often communicate with each other, and there are several households in New York City and New Jersey. One Tai Yai American in New York told me that there are about 100 Tai Yai Americans, but those who live in California, Colorado and certain other states only communicate with other Tai Lue Americans. This chapter does not discuss the Tai Dam Americans who reside in Iowa, as they originally lived in Vietnam and some of them in Laos. Most Tai Dam Americans migrated to the USA during the Vietnamese War, while some migrated during the Laotian Civil War. Tai Dam traditional culture, religion and language are very different from those of the Tai Lue, Tai Neua and Tai Yai, and the Tai Dam are not Buddhists. Moreover, I did not research the education and behaviors of Tai American teenagers born in the USA, even though they are the 
people who will determine the future of Tai Lue traditions and culture there.

\section{Methodology}

In this chapter, I will describe how the Tai Lue Americans remember and continue to preserve their traditional culture and customs while living abroad. Carrying out research on the Tai Lue Americans is very difficult, because naturally the geographical range that has to be covered includes SipsongPanna in China, northern Laos, northern Thailand, Muang Yong in Shan State, Myanmar, and the several states within the USA where the Tai Lue live. Fortunately, I had a good background prior to carry out my research. First of all, I am a Tai Lue and can speak the Tai, Lao and Thai languages, and I was a novice and a monk for 14 years in SipsongPanna. As a result, I had no problem communicating with my Tai informants, as I was able to speak Tai and write in Lanna Thai (the language spoken/written in the Lanna Kingdom, now northern Thailand) when interviewing them, and this allowed me to understand them when they talked about their Buddhist activities.

Second, I have a good relationship with many Tai Lue and Tai Neua Americans as a result of my visits to see them in February and March 2003, so that when they returned to SipsongPanna subsequent to my visits, they contacted me. Finally, I had already carried out fieldwork activities in SipsongPanna, northern Laos, northern Thailand and Muang Yong in Myanmar in relation to my previous work on Tai Lue Buddhism, which I carried out for Regional Center for Social Science and Sustainable Development (RCSD) at Chiang Mai University between October 2003 and June 2004.

In order to research the Tai Lue Americans, I first undertook fieldwork in SipsongPanna between December 2006 and January 2007, and again between May and June 2007. For this research, I visited some of their home villages and interviewed some of the older villagers and their relatives, and also visited some of the Buddhist temples which the Tai Lue Americans had helped to rebuild or repair through their donations. Because I had been a monk in WatPajay for several years during the 1990s and still had a good relationship with the monks there, the senior monks at the temple supported me when I did my fieldwork in the Tai Lue villages of SipsongPanna, in fact, two senior monks from the temple accompanied me during my fieldwork and when we arrived at a village or a temple, the monks there and the older villagers were pleased to meet us and answer my questions.

During July and August 2007 in the USA, I carried out six days' fieldwork in Hartford, Connecticut, spent 20 days in Colorado, five days in Phoenix, Arizona, and seven days in San Diego, California, then in early January 2008.

I also conducted five days' fieldwork in Rockford, Illinois and four days in Indiana. The Tai Lue Americans I met there were very pleased to see me because I am a Tai Lue from their homeland, and during my fieldwork I lived in their Buddhist temples and observed their Buddhist activities. Many Tai Lue Americans extended a great deal of hospitality towards me and invited me to share meals with them and stay overnight in their homes.

\section{The Tai Lue of SipsongPanna}

The Tai (Dai in Mandarin) are an ethnic group from Yunnan Province in China, and there are three branches of the Tai in China: the Tai Lue (or Lue) in SipsongPanna Prefecture, the Tai Yaa in Yuxi City and 
the Tai Neua in Dehong and other prefectures. Their total population adds up to over one million across the country. The Tai Lue reside in SipsongPanna and their population is around 340,000, but there are also Tai people to be found in Muang Yong, Burma and in Muang Sing Province in Laos, who are also considered to be Tai Lue, as these areas were part of SipsongPanna in the 19th century (GAO,1992). Added to this, there are many Tai Lue residing in northern Thailand, and these Tai Lue also migrated from Muang Yong in Burma and SipsongPanna. The Tai national identity is the same as that of the Lao in Laos, the Thai in Thailand and the Shan in Burma, and their language, religion (Theravada Buddhism), clothes, food and many other customs are quite similar.

SipsongPanna is the Tai language pronunciation of the Mandarin version, Xishuangbanna. This area is located in the southwestern part of Yunnan Province, a southwestern province of China, and is adjacent to Tibet. To its east and southeast, it borders Laos and to the south and southwest, it borders Burma (Myanmar). SipsongPanna is in a sub-tropical area with abundant rivers (including the Mekong River) and many hills and mountains. SipsongPanna has 12 different recognized native minority nationalities: the Tai, Hani (Akha), Yi, Laku (Lahu), Bulang, Jinuo, Yao, Hui (Muslim), Wa (Lawa), Miao (Hmong), Zhuang and Jingpo (Karchin). One ethnic group, the Kemu, is not yet recognized as a minority.

The Tai Lue were the rulers of SipsongPanna before 1953, and there were 44 Tai kings in SipsongPanna over the period from 1180 to 1953, after which the area was colonized by the People's Republic of China. During the Tai reign, Tai Lue communicated little with the Han Chinese, but a lot with people in the areas that are now Laos, Thailand and the Shan States in Myanmar. Prior to the 1950s, it was hard for the Tai Lue to get to Han Chinese areas, and it would take one month to walk or ride a horse to Kunming, the capital of Yunnan Province. However, on December 16, 1953, the construction of the Kun-Luo Road from Kunming to Da Luo in SipsongPanna was completed-representing the first time that cars had arrived in SipsongPanna from China (ZHENG, 2003, p. 275). However, it also took just a few hours to walk from the borderlands of Muang La County in Laos to some of the major towns in northern Laos, but took just only one or two days to walk from the towns which border Burma to some of the towns in Shan State. The Tai Lue in SipsongPanna practice Theravada Buddhism and use the Lanna-Thai written language, which spread from the Lanna Kingdom around the 12 th century.

\section{The Tai Lue in the USA: Suffering, Fearing and Fleeing}

Tai Lue Americans migrated to the USA due to the Chinese political revolution and the Laotian Civil War. The unstable society these events created caused them suffering, led to persecution and meant that they had to leave their homes. The first time the Tai Lue escaped from SipsongPanna was in 1949, for in November 1941, 48,000 Koumintang (KMT) soldiers of the 93rd Division of the 26th Army moved into SipsongPanna in order to prevent the Japanese army invading from Thailand (ZHENG, 2003, p. 75). On January 9, 1950, the People's Liberty Army (PLA) of the Chinese Communist Party (CCP) also moved into SipsongPanna (ZHENG, 2003, p.161) to attack the KMT army. The Tai Lue became involved in the conflict between the KMT and the CCP, and at that time DAO Dong-ting acted as the then King's right-hand man, because his son, DAO Shi-xun (Cao Morm Kham Lue in the Tai language), the real king, was a teenager and had studied in Nanjing and later in Kunming. The KMT Captain, LI (LI can-mou zhang), who was stationed in SipsongPanna, told DAO 
Dong-ting that he and his solders had already lost command to the CCP, and he forced DAO Dong-ting to lend him money and weapons. Since King DAO Dong-ting had neither weapons nor money to lend him, he hung Dao's queen by a rope. Fearing Captain LI and the coming Chinese People's Liberation Army (PLA), of whom King DAO Dong-ting had little knowledge, he led his young brother named DAO Dong-xin, their relatives and families (around 80 people in total) to Muang Yong in Shan State, Burma at the end of 1949 (ZHENG, 2003, pp. 129-140). After the CCP sent emissaries twice to contact him and persuade him to return to SipsongPanna, by early 1954 King Dao Dongting brought 64 of his relatives and family members, and another 711 Tai people back to SipsongPanna (ZHENG, 2003, pp. 257-269). While ZHENG mentioned that 711 returned to SipsongPanna, he does not specify how many remained outside of SipsongPanna, indeed, it is not known how many Tai Lue fled from SipsongPanna in total.

The second time the Tai Lue fled in large numbers was after the KMT was defeated by the PLA in SipsongPanna. At this time, the Tai Lue fled to Burma between 1953 and 1955, and many Tai people who helped the KMT escaped to Burma with them. Some of these Tai Lue settled in Burma or northern Thailand, while others migrated to Taiwan, however, the number of Tai people who fled at this time was relatively small.

The third and fourth migration waves happened during the Great Leap Forward (1958-1962) and Great Cultural Revolution (1966-1976) periods, with 1958 seeing the greatest number of people escaping. SipsongPanna started a land reformation process in January 1956 (ZHENG, 2003, p. 293), and under the leadership of Chairman MAO, Great Leap Forward policies swept across China in 1958 (CHU \& Tien, 1974, pp. 6-7). As a result of this, people in SipsongPanna were classified into six classes: big landlords, medium-scale landlords, small landlords, rich peasants, medium-wealth peasants and poor peasants. During this time the rich peasant and upper classes were attacked as enemies of the lower classes, and were not only forced to accept labor reform but were also beaten and tortured by other villagers, the Red Guard and the people's militia, and were taken to work in factories far from their homes. Seeing this kind of persecution, many Tai Lue people fled to Laos and Burma, while others who were taken to the factories escaped back home and then also led their families to Laos and Burma. However, some of them were captured by the people's militia and beaten to death.

Within the people's communes, people worked and ate together but did not have enough food. The Chinese government called on people to donate their cooking pots, even though they really needed these pots to cook themselves. The government advocated that the people produce vast quantities of steel, in pursuit of Western countries, and the slogan for the economy was "Surpassing the United Kingdom, catching up with USA". The starvation caused by these policies was one reason why the Tai Lue fled China.

During the Great Leap Forward, monks and novices were forced to disrobe and then to work in factories. A former secretary-general of the Buddhist Association of SipsongPanna told me that the person in the role of Soom Dect Aa Kaa Mooni, the highest position among the monks in SipsongPanna, was forced to disrobe and to feed water buffaloes in a village. Later, he committed suicide after being forced to fish in a pond - which he considered an evil deed as it broke the Buddhist precepts. During the Cultural Revolution, religious activities were banned completely, all Buddha statues were destroyed and Buddhist texts were burned; temples were destroyed or their usage changed, they were either made into schools or public storage areas. As a result of all these activities, many monks fled to Laos and Burma. 
Therefore, at this time, many Tai people who feared for their lives escaped to Laos and Burma, some going to Burma then transferring to Laos. In some villages close to the Lao border, such as Ban Ler village and Ban Ang village in Muang La County, every villager escaped to Laos. Some took their families with them, but some could not, while others returned to SipsongPanna not long after they had fled to Laos. KhananSer, now 72 year-old and the head of Buddhist activities in Chiang Dai Village, Muang Mang in Muang La County, told me that he also escaped to Muang Sing in Laos in 1958, and that nobody persecuted him there, he simply fled with other people. He returned to Chiang Dai in 1959, and told me that many people returned to their home villages when they knew they would be safe.

However, the Tai people's traumas did not end after they had escaped from China; they continued in Laos. Many Tai Lue Americans told me that because they were newcomers they were often discriminated against by the local Lao people, including the native Tai Lue. The local Lao police defrauded them of their property, as the following statement from Ai Lor's memoirs ${ }^{1}$ shows:

...When we arrived in Muang Sing, the Lao police came to inspect us and took our valuable items, saying they would keep the things safe for us, until we had houses. The police cheated us, as they did not return those items at all. We went to ask them may times to return our property, but they gave no response. Some Tai Lue cried and cried due to that. Some Lao officers were kind and explained Lao policy to the refugees, but others took the Tai Lue's valuables...Those refugees whose Tai Lue relatives or friends had moved to Muang Sing previously were encouraged to live with them, but refugees with no Tai Lue relatives or friends built new villages, such as Muang Poo Kha (a Tai Lue town). The local Tai Lue complained that the newcomers were competing for their food and that everything was being eaten by the newcomers... (p. 6)

After the Tai Lue settled in Laos, they thought they would be able to spend the rest of their lives there peacefully, however, the Laotian Civil War broke out in 1962, during which time the Lao authorities split into two: the Old Lao and the New Lao (or Red Lao). Many Tai Lue men were forced to join the Old Lao Army, while others joined the New Lao Army. Even those Tai Lue who did not participate could not avoid the impacts of the war, as when the Old Lao soldiers came to the villages, they would accuse the Tai Lue of helping the New Lao Army and torture them. Then, when the New Lao soldiers came to the villagers, they did the same thing.

During the war, many Tai Lue were killed. In order to avoid the war, especially when the Old Lao Army was defeated by the New Lao Army, many Tai Lue fled to Thailand with other refugees, but during their travels, many were killed by the New Lao soldiers who chased them. Some Tai Lue American elders told me that many people were killed during their escape, especially when they crossed the Mekong River from Laos to Thailand. To do this, they had to use boats or bamboo rafts, but because they were fleeing, the boats and bamboo rafts which they used were not safe, and many sank, killing the occupants. Some people swam across the Mekong River, with a number of them drowning, while others still were shot by the New Lao soldiers as they tried to cross.

Some of the Tai Lue who fled to Thailand returned to Laos after the civil war ended and the new Lao government had taken power, however, those who had participated in the war or supported the Old Lao Army were taken for "re-education". Realizing that another communist revolution was taking place, as in China before, many returned to Thailand.

\footnotetext{
${ }^{1}$ A Memoirs in Tai Lue Script and Tai Lue poem form written by Ai Lort, an old Tai Lue American man. When I interviewed him at his home in San Diego, he lent me the book.
} 
However, the Tai Lue suffered more trauma after arriving in Thailand. Because they were Lao refugees, local Thai thieves attacked and robbed them when they arrived, killing some. They then had to endure a hard time in refugee camps set up by the Thai government, because they were not Thai citizens and their lives were strictly controlled.

Refugees who had crossed into Thailand in 1975 and 1976 reported instances of brutality carried out by Thai people...[who] discovered that [the] refugees had no rights, no resources, [were open to] abuse [and had] no ability to bring charges against thieves, murderers, extortionists or rapists. (Hamilton-Merritt, 1993, p. 476)

Some of the Thai officers guarding the refugee camps tried to extort money from the refugees, contacting Thai business people so they could sell them goods at high prices, then attempting to delay the migration process of some refugees, who were trying to go to the USA. Even when they escaped the refugee camps they were not free, because they had no Thai identity cards, and so were fined by the Thai police if caught.

Fortunately, however, the refugees were able to perform their Buddhist rituals in Thailand again, and they built a Buddhist temple in Ban Dhong Refugee Camp near Ban Dhong Village in Chiang Rai Province, where they could practice their Buddhist traditions. The Tai Lue, like other refugees, were given the right to choose which country they wished to migrate to, and most of the Tai Lue chose the USA, though some migrated to Australia, France and Canada. After having been through so many disasters and tragedies, the Tai Lue were finally able to lead peaceful lives in a developed country, where they had the ability to practice their traditional culture and customs.

\section{The Survival of Tai Lue Traditional Culture in the USA}

For Tai Lue traditional culture to survive, as with any culture, it needs a social space, and the USA is a space within which migrants from all over the world have the freedom to practice their cultures-providing the Tai Lue with the space needed to reorganize, modify and persist with theirs. Tai traditional culture is very strong in the USA, though the population is small. However, their strong traditions have prevented the Tai Lue Americans from completely immersing themselves in American culture, and also their traditions and behaviors have not been easily assimilated by American culture itself, though the space provided by the USA has offered them a good chance to maintain yet modify their own.

Other migrants, especially Southeast Asian refugees, have provided the Tai Lue Americans with an example of how traditional cultures can be practiced in the USA, and from this they have been able to imitate and learn. If one regards the Tai Lue Americans as a cultural body, it is not completely isolated from the rest of American society, but connects quite strongly with the Lao and Thai cultures, which are similar. The organizations and activities of the Hmong Americans who migrated to the USA at the same time as the Tai Lue Americans, have provided them with a reference point for practicing their own traditional culture. For example, when the Hmong Americans hold events and activities, Tai Lue Americans may be invited to attend.

Tai Lue Americans maintain close contact with each other, and in many places have set up Tai associations in order to help maintain their traditional culture. Buddhist temples are their cultural and activity centers, so they have built a number of their own temples, or go to worship in Lao and Thai Buddhist temples instead. Aside from Buddhism, they have also been able to maintain their non-Buddhist religious behaviors, such as their language, food and clothes, which are traditional elements of their lives. Tai Lue Americans have also inter-married with others in the Tai Lue community and have maintained their traditional marriage rituals. 


\section{Theravada Buddhism}

Theravada Buddhism is the strongest element affecting Tai Lue traditional culture, and in the USA the Tai Lue have been able to raise the funds needed to build their own Buddhist temples. Buddhist temples seem to be more important for Tai Lue American elders and adults in the USA than they are in SipsongPanna, because it is only the temples that can provide them with places in which to practice their traditions, and to gather and enjoy their own forms of entertainment, probably because of their small population within a large, Western society makes them feel more isolated. Although some have Tai American neighbors, most live in separate communities, and this is quite different from the situation they experienced in SipsongPanna and Laos. The Tai Lue American elders told me that they often feel lonely because they are not able to chat with their neighbors as much as they did in Laos and in SipsongPanna, so the Buddhist temples that do exist help to reduce their sense of isolation. When they gather and perform their traditions in these temples, they can meet and talk to their relatives, to friends and other Tai people.

\section{Building Wat Buddha Punyaram Temple}

Wat Buddha Punyaram Temple is located in Brighton, Colorado, having moved from Westminster in Colorado during April 2005. Among the Tai Lue American Buddhist temples, it is the biggest and has the largest number of Tai Lue American devotees-about 370 families. The name of the temple literally means "garden of merit", and there are four monks at the temple: the Abbot-Cao Sithi (about 40 year-old) and three others about 30 year-old who are Tai Lue and from Tachileck in Myanmar, though their parents are from SipsongPanna. One of the monks, aged 70, is Tai Lue and was born in Muang Sing, Laos and then was ordained as a monk in Colorado, while another is Tai Yai and is about 40 year-old from Jengtung in Myanmar.

At first, after they migrated to the USA, the Tai Lue went to worship at Lao and Thai temples, but felt that the Lao and Thai people discriminated against them. They told me that the Thai people shouted at them, telling them to go home, so they were forced to build their own temple. On July 4th 1994, they rented a house in Westminster, Colorado, and set up their own temple there, and after several years of fundraising, had enough funds to buy the house outright, decorating half of the house as a simple worship hall so that they could perform Buddhist activities. When I visited them in March 2003, I lived in the temple for two weeks. I saw that the worship hall was simpler and smaller than a formal Buddhist hall in SipsongPanna. The house had five small bedrooms in which the monks lived, and a kitchen. The basement was connected to a yard in which they built another kitchen for lay people, and as a result, the basement, yard and second kitchen were where the Tai Lue Americans performed their non-Buddhist activities: cooking, eating and holding entertainment activities such as singing and dancing.

Later, the house and the parking area became too small to hold all their Buddhist activities - as more Tai Lue Americans moved from other states to Colorado. As a result, they then bought a four-acre farm with a big house and a stable in Brighton, Colorado, on which to build a new temple, selling the old house. They then invested $\$ 407,800$ in building a big Vihara (Buddhist Hall) and constructed an outside parking area around the hall. They expanded and decorated the stable - turning it into a dining and entertainment area. The total cost of the land and the reconstruction activities was $\$ 705,000$, paid for with the income earned from selling the old temple, from their own donations and from the Buddhist activities held at the temple. However, this was not 
enough to cover the costs, so they also had to borrow $\$ 500,000$ from banks. However, the income they then earned allowed them to pay-off a large part of their debts, and by August 15th, 2007 owed the banks just $\$ 280,000$.

It is not easy to build a Buddhist temple in the USA, and particularly difficult to build a temple as big as the ones in SipsongPanna. Both the construction of the temple and the use of the land costs a lot of money, and the structure and style cannot be replicated completely, due to US construction regulations. As a result, the design of the new temple had to be altered, so as to gain permission from the local architecture bureau, and because of this, the architectural style of Wat Buddha Punyaram is different from the temples in SipsongPanna and in Laos, but the function of the temple is the same. The designers of the temple were Cao Sithi-the Abbot of the temple, and another young Tai Lue American - a layman, who told me that they had to make many design changes in order to secure permission from the local construction bureau.

The opening ceremony for the new Buddha hall was held in June 2007 and to the extent it was possible a traditional temple dedication celebration. The temple committee invited three senior monks and me (including KrubaLongjorm) from WatPajay in SipsongPanna to attend the ceremony, as they wanted monks and lay people from home to participate, and believed we would be able to get a US visa. Two monks participated in the celebration, but KrubaLongjorm and I could not attend because KrubaLongjorm's passport was due to expire within six months and so he could not get a US visa, and I did not have time. Several senior monks (Tai Lue) in Tachileck and Jeng Tung (Tai Yai), Myanmar, were invited to manage the Buddhist ceremony for the new hall, and many Tai Americans from other states were invited to attend. In the end a wonderful ceremony was held involving entertainment activities such as Tai song and dance.

Tai Lue Americans in Colorado are happy with and proud of their new temple, though the architectural style is not quite as elegant as in SipsongPanna, and the temple is a little far from their houses - they usually have to drive for 15 to 30 minutes to get there. The new Buddha Hall can hold around 1,000 people and has parking space for more than 100 cars. The house bought for the temple is quite big and has six bedrooms, three bathrooms, a kitchen with a dining room, two living rooms and a garage which can hold three cars. The house is used as the living space for the monks, and the reconstructed dining room and entertainment area provides Tai Lue lay people with a kitchen, a dining hall and an entertainment and activity area in which they can hold their Buddhist and other activities.

\section{KhaoVarsā in Wat Buddha Punyaram}

Varsā is a Pali word and means "summer retreat during the wet season". The vars $\bar{a}$ period lasts three lunar months, beginning in late June or early July and ending in September or October. When the monks enter the varsa they are not supposed to leave the temple again until the ork, or end of the wet season. It is said that the regulations for varsā were developed by Śākyamuni Buddha, who saw many monks leaving the temples and stepping on peasants' crops, so decided they should meditate inside their temples instead. This rule is maintained by Theravada Buddhists in Southeast Asia, and the days marking the beginning and end of the wet season are important festivals. In SipsongPanna, KhaoVarsā day is held on the waxing moon day of the ninth month of the Chulasakaraj Calendar and OrkVarsā (the end of summer lent) is held on the waxing moon day of the twelfth month of the Chulasakaraj Calendar. 
I arrived in Denver on July 26th 2007, and stayed in Wat Buddha Punyaram Temple, in time to participate in the KhaoVarsā celebration there on Sunday July 28th. If Buddhist festival days fall on a Monday to Friday, the Tai Lue Americans move them to the weekend, because many of them have to work and do not have time to participate in the activities, and some older Tai Lue Americans who cannot drive have to wait for their children or grandchildren to be able to drive them to the temple at the weekends.

When I visited the Tai Lue community on July 27 th, the eve of KhaoVars $\bar{a}$, I stayed at a friend's house as her family prepared offerings for the festival, including apples, bananas, small candles and flowers. The next morning, my friend got up early to prepare the sticky rice, which is one of the most important offerings during the ceremony. These activities are very similar to what happens in SipsongPanna, and my friend also prepared offerings for me to give at the temple. After breakfast, my friend, her husband, mother and I drove to the temple and it took us about 15 minutes to get there. When we arrived at the temple (at 9 a.m.), I saw several cars parked there. In SipsongPanna, since temples are located very close to villages, lay people walk to them and usually arrive between 7 a.m. and 8 a.m. However, Tai Lue Americans go to the temples later than in SipsongPanna, and on the morning I visited, by 9:30 a.m. around 100 cars were parked outside the Buddha Hall. Each person arriving at the temple dropped one small sticky rice ball (bite-sized) into each of the two Buddha bowls set to the side of the Buddha image, on the altar. After that they left the Buddha Hall and went to the temple's deity pavilion (for the deity who protects the temple) in the temple yard and dropped another two small sticky rice balls at the pavilion. These actions were similar to what would happen in SipsongPanna.

The group activities in the Buddha Hall began at 10 a.m., thereafter following a process similar to that in SipsongPanna temples. First, all the Buddhist devotees worshiped the three treasures - the Buddha, Dharma and Sangha, then the three monks chanted (one monk lives at Wat Lao LueSouvannaram in Kansas) the Mangala Sutra. The BorJarn (the head of lay people) recited the Sutras in Tai, saying that all the offerings would be sent to heaven and to the offerers' dead relatives in hell, where they could share the offerings. The monks then led all the people in the Buddha Hall in meditation for five minutes. The next ritual in the ceremony that year was the begging for alms ceremony, in which all the lay people formed a line in order to drop their money, small candles and small sticky rice balls one by one into the 12 Buddhist bowls set on a long table in the front corridor of the Buddha Hall, with each person placing one US dollar into each bowl. This activity is not usually performed in SipsongPanna temples, but is popular in temples in Laos and Thailand, so this practice has obviously been picked up from the Lao and Thai Americans. Traditionally, in SipsongPanna begging for alms was an activity in which monks carried bowls to the villages to beg for food, but recently, this activity has stopped. One Tai Lue American told me: "This kind of begging for alms ritual at least helps the temple to collect more money for its future construction". After the begging activity was finished, the lead members of the temple collected and counted the money placed in the 12 Buddhist alms bowls, and for that year the total amount of money collected was $\$ 2,450$, with the total announced to all the people in the Buddha Hall. This event represents an important fund raising activity for the temple, in terms of its maintenance and construction, and in support of its other Buddhist activities.

The next activity held at the ceremony involved the monks reciting the Sutras and each lay person dropping a little water into his or her own bowl and praying for good luck. The dropping of water represents asking Buddha and the deities to note any good deeds, while praying ensures that the food and offerings will be 
sent to any dead relatives in hell. After the water-dropping activity had ended at 11:30 a.m., it was time for the monks to have lunch, because monks are not allowed to eat after noon. This rule regarding the monks eating is actually ignored in SipsongPanna, but is adhered to strictly in Laos and Thailand, and Tai Lue American monks have decided to retain this rule, due to the influence of Lao and Thai Buddhism. The monks then went to have lunch in their living area, because generally they are not supposed to eat with lay people. The Tai elders then had lunch in the Buddha Hall, while all the other lay people went to have lunch in the dining and entertainment room, the lunch being provided buffet-style. I was invited to sample the buffet, which was a wonderful meal consisting of Tai food. The temple provided food for everybody who came to the temple on the day of the ceremony, but this is not a part of the rituals held in the Buddhist temples in SipsongPanna. In SipsongPanna, it is usually only the elders who partake of food in the temples; their children, grandchildren or young relatives cook at home and send the food to them, but eat at home themselves because the sponsors of the activity have no ability to provide them with food.

After lunch at the temple, the young people and adults sang and danced in the entertainment hall, which has good light and sound equipment, and musical instruments are also available. Some people played cards outside the entertainment hall, and then at around 3 p.m., people started filtering home. However, after lunch, the elders stayed in the Buddha Hall listening to a monk read a Buddhist Jataka text (in SipsongPanna, the monks would read several texts). By around 4 p.m. all the lay people had gone home, and only the three monks and I stayed at the temple which by this time was very quiet. This situation is different from SipsongPanna, as many monks stay in the temples and villagers filter in and out after the activities have ended meaning the temples are not nearly as quiet. To be honest, I felt a little lonely in the temple, so asked the monks what they were feeling, and they told me that sometimes they also feel lonely, but they are used to it.

\section{Offering-to-the-Dead Ritual}

The "offering-to-the-dead" ritual is called danjormkoondhai in Tai, and it involves offering items to the dead relatives who are thought to reside in hell. Tai Lue Americans still perform this ritual in the USA, as they do in SipsongPanna, as it represents an important way for the living to respect and remember their dead relatives. In SipsongPanna, some families accumulate funds over several years in order to hold this ritual, as performing it is quite expensive. As a result, most families do not carry out this ritual for several years after their relatives have died, though richer families will do it sooner. This ritual is normally held during varsa $\bar{a}$ (the summer retreat).

When I stayed at Wat Buddha Punyaram, I observed three families holding this ritual. On August 4th (Saturday) and 5th (Sunday), two families held the ritual; the Ai Mai and Ai Seng families - the Ai Mai family for their dead father and a dead daughter, and the Ai Seng family for their dead daughter.

Ai Mai was born in Ban Yang Kang village in Muang Long, SipsongPanna, and was 10 year-old when his parents escaped Muang Long during the Great Leap Forward period in 1958, arriving in MuangHae in Shan State, Burma, then in 1960 moving to live in Ban NuongNgeun in Muang Sing Province, Laos. He married in 1966, and in 1967 moved with his wife to live in Ban Mai Jeng Kham in Muang Sing Province. Ai Mai had three children; his wife and first child (daughter) died during the Laotian Civil War, and in 1975 his family moved to Chiang Kuang refugee camp in Chiang Rai Province, Thailand. In 1978, they migrated to Denver, 
Colorado in the USA and he married a Laotian woman in Denver in 1980. His father died in 2006, and so when I was there he held the ritual for his daughter and his father, but not for his wife. According to Tai custom, when one's spouse dies, the living spouse must "cut off the relationship" with the deceased, otherwise the deceased will come to take him or her to hell. Another belief is that an adult or elderly person should remarry after the partner has died, and in this instance, the living spouse does not hold the ritual for his or her deceased partner.

The offerings made at the ritual are various but depend on the family's economic situation. A model of the house or pavilion is the least expensive but most important offering for each dead person, but most offerings are commodities that suit the needs of the dead, taking into account their age and sex. The family may even prepare a type of food that the dead person liked when he or she was alive. Offerings can also include old items that the dead person used, though now new items are usually bought. After the ritual has been completed, the offerings are donated to the temple, and if those offering bought the objects at a high price and want to take them back, they can ask the abbot of the temple to return the object to them paying a voluntary fee in return. Since the USA has abundant material products, Tai Lue Americans are able to prepare more offerings than they do in SipsongPanna; some families even offer small TV sets to their deceased relatives. Ai Mai prepared two sets of offerings for his father and his daughter when I was visiting, with offerings such as clothing donated to the temple after the ritual had finished. The ritual has three key meanings: (1) the objects the dead person used are believed to have evil attached to them, so the dead person needs to continue to use them; (2) the living relatives will miss the dead person too much if they themselves use these objects; and (3) only when the objects have been donated to a temple can they be passed on to the dead person. For the ceremony I attended, two cars that had been used by the two dead relatives were offered to Wat Buddha Punyaram after the rituals had finished.

Ai Seng's daughter died while in her thirties, and before she died, she married and had a daughter, with her widower remarrying. The offering ritual I attended was thus held by Ai Seng's family, and the widower and his new wife came to help. On the morning of August 4th, Ai Seng invited the Abbot and one other monk (the third monk was attending English classes at school) to chant the Mangala Sutra at his home. The Abbot, the monk and I drove to Ai Seng's house, and several Tai Lue elders and Ai Seng's relatives also came to listen to the monks' chants. After the chanting was over, the family offered the monks lunch and they then chanted blessings for them. I had lunch with the lay people who came to participate in the ritual, because as I mentioned above, lay people do not eat at the same table as the monks. After lunch, we left for the temple, but Ai Mai did not invite the monks to his house. In SipsongPanna, monks must be invited to the offerers' homes to chant the Mangala Sutra and to read Buddhist texts, sometimes from the afternoon until midnight. I asked the Abbot the reason for this difference, and he said monks in the USA are few and far between, and the Buddhist devotees are very busy, therefore, some Buddhist rituals which are not so important are omitted.

In the afternoon of August 4th, the two families took their offerings to Wat Buddha Punyaram Temple. In SipsongPanna, family members and relatives would carry the offerings and organize a procession, walking from home to the temple, and some of them would play drums and gongs, and the whole village would know why they were doing so. However, it is not possible to do this in the USA because one might annoy the neighbors. Ai Mai's and Ai Seng's family both made their offerings in the Buddha Hall, where three house 
models had been set-up and with the offerings placed around the models. The models were made of good quality wood painted with colors; they were of a better quality than the models made in SipsongPanna.

Relatives and friends were invited to participate in the ritual, with some attending from other states, for example, I met one guest from Kansas and two from Texas while I was there. The two families' relatives came to the temple to donate money and offer items to the families, though most of them just gave money. This money belongs to the family after the ritual, not to the temple. After each relative had given an offering to the family, an elder from that family recited a blessing for them, and at the same time, each monk was invited to sit around the models of the houses and read Buddhist Jataka texts. After the offerings had been given, the givers listened to the Buddhist Jataka texts and went to eat in the dining hall, where the two families prepared food for their own relatives, though most of those attending were guests of both families. As a result, they were able to partake of food and drink from the two families. After that, some people had dinner and drank beer while others sang and danced in the entertainment hall. Around 10 p.m., more people participated in group Tai or Lao dancing, and then at 11 p.m., they began to leave gradually. At midnight, the entertainment stopped, with some elders, relatives and family members sleeping in the Buddha Hall in order to guard the offerings.

Table 1

Service Teams Under the Tai Lue American Association of Colorado

\begin{tabular}{llll}
\hline No. & Name of Team & Number of People & Responsibilities \\
\hline 1 & Education & 3 & Contacting schools \\
2 & Construction & 6 & Temple construction \\
3 & Secretary & 4 & Composing and delivering documents \\
4 & Accountant & 5 & Managing funds and contacting banks \\
5 & Contact & 3 & Contact with other Tai Lue Americans in Colorado \\
6 & Entertainment & 3 & Entertainment activities \\
7 & Sport & 4 & Organizing and encouraging participation in sports \\
8 & Elders' & 20 & Leading Buddhist activities and activities for the elderly
\end{tabular}

The next day, August 5th (Sunday), was the day of the Sila offering festival. This and the offering-to-the-dead ritual were thus performed together, and at the same time an additional step in the offering-to-the-dead ritual was carried out whereby two monks were invited to read a Buddhist Jataka text inside the model houses - offering their chants to the dead relatives.

In the afternoon, the two activities were completed and most of the offerings were left to the temple, though the families involved kept the money which the relatives had donated to them. The next day, the three models were thrown away into the temple yard, and I must have seen at least 10 models thrown there, as they cannot be used twice. Ai Mai told me that one model cost him \$2,000 to make. In SipsongPanna, the models are much simpler, sometimes, they are even just made of bamboo, and the guests arrive at the ritual to make an offering then have a meal at the host's home. However, it is not convenient to carry out these activities at people's homes in the USA, so some Tai Lue Americans instead go back to SipsongPanna to hold the ritual, because it is cheaper there and more relatives can participate. I will provide further details of this later. 


\section{Tai Lue American Associations}

Tai Lue American associations play a very important role in the Tai Lue's lives, as well as help maintain their traditions in the USA, and as with other Asian diaspora, Tai Lue Americans realize that establishing Tai Lue associations helps them to survive abroad. There is no united association of Tai Lue Americans, but instead several individual Tai Lue American associations in different states, such as in Arkansas, Colorado, Connecticut, Illinois, Kansas and San Diego. All these associations are connected closely with a Buddhist temple, so the establishment of a Tai Lue American association and the building of a Buddhist temple always go hand-in-hand. The Buddhist temples provide the people with, not only space to perform their religious activities, but also act as places where they can gather and hold group activities, including entertainment.

In Colorado, the Tai Lue American Association seems a well-organized institution, and is divided into two lead committees: the Buddhist Temple Lead Committee and the Lay People's Lead Committee. The committees are elected for two years, and the Buddhist Temple Lead Committee is responsible for the affairs of the temple and Buddhist activities, and has one chief and two vice-chiefs. The Lay People's Lead Committee is responsible for organizing people's daily events, such as weddings, funerals and other activities which require members' help, and this committee has a chief and four vice-chiefs. The chief of the Lay People's Lead Committees represents the highest position on either committee. Under the two committees are eight service teams (see Table 1), however, one monk from the temple and some of my informants told me these teams do not act as they are meant to.

The Tai Lue households, as members of the Association, are divided into 10 teams that are responsible for the ten Sīla Day Offering Festivals in vāsar, as discussed in the previous section. Households must pay a membership fee, and the membership fees are used for group expenditures, temple construction activities and are donated to help the families of the deceased with funeral rites, and those who incur medical costs.

Those Tai Lue American associations with smaller memberships do not have as many teams as the Colorado Association, but they have similar functions in that they enable Tai Lue Americans to communicate, gather and help each other. A few families who live too far from all of these associations may join in a Lao or Thai association, and usually follow the behaviors of the Laotians or Thais. For example, there are two Tai Lue American families in Florida who participate in the Lao Association there and go to worship in the Lao Buddhist temple-WatNavaram in Sanford.

\section{Tai Lue Food}

People from any ethnic group or nationality produce and are used to eating their own style of food, as this is a reflection of their identity and of habits developed over time, and they may feel uncomfortable if they cannot do so. As a result, when people migrate, they often maintain their traditional food styles. Similar to this, Tai Lue Americans have brought their Tai style food to the USA, and the Tai Americans born in SipsongPanna, Laos or Thailand (in refugee camps) prefer to eat Tai food - cooking and eating it at home and in their temples, particularly during special activities and events.

The main characteristics of Tai food are that it is sour, spicy and bitter, and uses ingredients such as lemongrass, lemon, garlic, shallots, leeks and ginger. Many kinds of Tai, Lao and Thai ingredients are the same and are sold in many markets in the USA, though many Tai Lue American families also plant these ingredients 
and other vegetables in their yards, such as peppers, cucumbers, pumpkins and cabbages.

Sticky rice is a staple Tai food, and Tai Americans, in particular the Tai elders, prefer sticky rice over other types of rice. As a result, when they hold gatherings at home and/or in the temples, they always eat sticky rice, for it is easy to buy at the local markets. They also like to use traditional steamers to steam the rice and traditional containers, which are made of bamboo, to hold the cooked sticky rice, rather than the modern containers normally found in the USA. Traditional steamers and bamboo containers are sold by Tai and Lao Americans, or they can usually bring them back to the USA when they go to Laos or SipsongPanna. The baking of meat is popular among the Tai people in SipsongPanna, so holding barbecues is a favorite pastime of Tai Lue Americans, and barbecue tools such as electric baking ovens provide the Tai Americans with more convenient cooking instruments than at home in SipsongPanna.

However, some of the favored Tai ingredients cannot be bought from American markets, such as nammee boo (crab sauce), dried buffalo, cow skin and bitter bamboo shoots, so they usually bring them back from SipsongPanna or Laos after they have visited home. Their relatives in SipsongPanna also mail food items to them, though their dietary requirements sometimes conflict with the US authorities' import and export regulations, for example, buffalo and cow skins are favorite Tai food items (they are minced before being eaten), but their importation is forbidden by the USA. Ai La in San Diego told me that he had previously brought 12 pounds of dried buffalo skin when he came back from SipsongPanna, but the customs officials had confiscated it when he arrived at Los Angeles airport. Sometimes, the airport customs officials do not check, so the Tai Lue are able to bring the food into the USA, but to get around the laws, an elderly Tai man in Connecticut makes dried buffalo and cow skins himself. When I visited and stayed at his home, I ate it with him, and the taste was the same as it is in SipsongPanna.

There is a generation gap among Tai Lue Americans with regard to food, as the elders do not like to eat Western food, whereas their grandchildren, those born in the United States, do not really eat Tai food at all; some like it, some do not. Some of the parents told me that their children will not eat any of the food they cook for them.

\section{Tai Lue Language}

Language is a symbol of national identity, and as I mentioned in the first section, the Tai Lue language is similar to Lao and Thai, and is also close to the northern Thai dialect. Like their culture, the Tai Lue American language is an amalgamation of the Lao, Thai and American English languages; they mix them together. In Tai American temples, I found that Lao, Thai, Lanna Thai (the Tai writing) and English are usually all written in the documents and on the signs. The Tai Lue from SipsongPanna and northern Laos use a Lanna Thai writing system (also named tua tam, meaning Buddhist script, or the old style Tai script), which spread into SipsongPanna from what is now northern Thailand along with Buddhism around the 12th century.

In Wat Buddha Punyaram, Buddhist texts are usually written in Lanna Thai because they were brought from SipsongPanna, northern Laos and Tachilek in Jengtung, Myanmar, where Lanna Thai is used in Buddhist temples. However, most Tai Lue Americans read Lao, and there are three main reasons for this: (1) It is harder to learn Lanna Thai than Lao writing; (2) The Tai Lue elders and adults learned and used Lao writing when they lived in Laos and before they fled to Thailand; and (3) Lao writing can be used to communicate with Lao 
people, of whom there are a larger number than the Tai Lue. As a result, Lao writing is more popular than Lanna Thai for Tai Lue adults and elders in the USA, and their invitation letters, announcements and other documents are usually written in Lao, though sometimes in English.

Since the Tai people left SipsongPanna during the Great Leap Forward and Cultural Revolution Movements, Mandarin Chinese did not have a chance to influence them much in SipsongPanna, so only a few of them can speak a little bit of the Han Chinese dialect. As far as I know, few of the elderly Tai Lue Americans can speak Mandarin, however, several Tai women who have married Tai Americans since the 1990s can speak Mandarin. The Tai Lue told me that when they go back to SipsongPanna, they usually fly to Thailand and then transfer to SipsongPanna, or alternatively go from Thailand to Laos and then to SipsongPanna, instead of flying from the USA directly to China, because they cannot speak Mandarin and most Chinese people in the airports and at restaurants do not speak English.

Tai Lue Americans still maintain their oral history, and those Tai Lue over the age of 25, and especially those who were born in SipsongPanna, Laos or Thailand, communicate in the Tai language. Those above 60 years of age can speak just a little English, especially the elderly Tai Americans who have never worked in the USA because they were too old to get the elderly annuities when they migrated. As a result, these elders speak the Tai language most and sometimes also speak Lao and Thai. The children's Tai Language instruction occurs within their families and as part of Tai Lue American communications, as there are no institutions offering Tai language courses. Most Tai Lue American teenagers do not want to speak Tai, even though they can understand it, so when their parents and grandparents speak Tai to them, they like to respond in English. When I met Tai American teenagers and said "sabaidee" (hello) to them, they replied with the same, but when I tried to speak more Tai with them, they were shy and spoke only a little, or did not reply at all. However, some Tai Lue American children and teenagers, whose grandparents and parents intentionally taught them to speak Tai, can still speak Tai fluently.

Some leaders of the Tai Lue American Association of Colorado and the abbots at Wat Buddha Punyaram told me that they were thinking about starting a children's Tai language course at the temple, learning from Laotian and Thai people who offer language programs to children in the summer holidays. However, Wat Buddha Punyaram faces many difficulties in trying to do this. First, because most Tai Lue Americans live far from the temple, it may be hard for their parents to drive their children to the temple every day during the course. Added to this, many parents will not let their children live in the temple. Second, it is hard to set the course content; the children are likely to get bored if they are taught only one language, though the monks at the temple could teach the children language, and a basic knowledge of Tai culture and Buddhism, as well as teach them to practice basic Buddhist activities. It would be nice if the children were also taught Tai dance, but it may be difficult to find a volunteer dance teacher who can teach them this. Third, it is hard to determine which written language should be offered to the children: Lanna Thai, Lao or Thai. When I visited Wat Ratanaram (a Tai Neua temple) in Rockford, Illinois, I met a Laotian man who came to talk with the Abbot about offering a Lao language course to Tai children, as Lao people and their language are influencing the Tai Lue and Tai Neua Americans. Another reason for this is that, as yet there has been no Tai Lue language course offered to Tai Lue children in the USA, and the Tai Lue may find it quite difficult to do this as they live in such small groups, scattered across dispersed locations such as Hartford in Connecticut and Phoenix in Arizona. 
Learning Lao will, therefore, make it much easier for them to communicate with the Tai Lue in other parts of the country.

\section{Group Living}

Tai Lue Americans have maintained some of their traditions, and on the one hand, these traditions have left them somewhat unwilling or unable to fully integrate into US society, while on the other hand, their traditional habits have helped them survive and maintain their traditional culture within the country.

In terms of their living spaces, they still like to live in houses with yards, as they did in Asia; they do not like to live in apartments or in urban areas. Those who do live in apartments find it shameful, so most of them work hard to enhance their living conditions, live in good houses and drive new cars. Many of them told me that their American neighbors often ask them how they manage to have better houses and newer cars, even though they have been living in the USA only a short time, around 20 years. They told me the main reason for this is that they work hard to save money in order to buy houses, which are the most important asset for them, and they often work overtime. One of my informants, aged 50, told me that when he was in his thirties he often worked for 20 hours each day and only slept for around three hours. I think the other reason for this is that Tai Lue Americans usually cook their own food and plant as many ingredients and vegetables in their yards as they can, and so they are able to save more money than their neighbors, who often like to spend their money in restaurants. Second, Tai grandparents usually help to take care of their grandchildren, and this can also save a lot of money. Third, they do not travel a lot; most of them have not been to New York and when they go back to China they only visit their relatives in SipsongPanna. Very few of them have traveled to any other parts of China.

Living as a group is their tradition and is very important in helping them survive and maintain their traditional culture in the USA. In China and Laos, Tai Lue people usually live in villages where relatives and neighbors can easily communicate with and look after each other, so when they go outside their homes, they can easily see and talk with neighbors and villagers. Since the Tai Lue moved to live in American communities, they have not been able to fully adapt to the way people live, and as a result, have maintained some of their traditions, in order to help each other survive. For example, Tai Lue relatives like to live as near to each other as possible, though sometimes it is difficult to live as neighbors in the strictest sense. Tai Lue American parents usually live in the same houses as their married children, so they can help to take care of the grandchildren. Also, living nearby or in the same community is convenient when it comes to helping each other when they are in need or need to gather together.

There are 12 Tai Lue families living in Phoenix, Arizona, and most of them are relatives. An elderly Tai Lue American couple I met have two daughters and three sons, all of whom live in Phoenix, and they live across three houses. The elderly couple live in a big house with their second son, who is married but has no children, and their third son, who is about 30 year-old and has not married. For the second daughter, who is in her fifties, her husband and three children have just moved from San Diego to Phoenix, and they also live together in the parents' house. The first son and first daughter both have children and have their own houses, about 10 minute drive from the parents. In Phoenix, some Tai Lue American families are neighbors and live within walking distance of one another, but those located further away still only live 10 minutes or so away. 
They told me that they often gather, cook Tai food and eat together. Similarly, in Indiana, Ai Mai Peng's house is next to his younger brother's, and their parents live with the eldest son (Ai Mai Peng), as it is convenient for them to take care of their second son's house and children. The two older sisters also live in the same community, just a five minute drive away.

It is also common for Tai Americans to work at the same company or factory, for when one person finds a job at a good company, he or she introduces others to that company also. Yu Bun, who married the second son of the old couple I mentioned above and who lives in Phoenix, managed to get a US fiancé's visa and came to the USA in June 2006. After undergoing English training for several months, her sister-in-law, who lives with them, introduced her to the company she works for, an electronics plant in Phoenix, where she had been working for several months. Now, her sister-in-law can pick her up on the way to work and they travel home together. In Indiana, there are 11 Tai American families living in the same community and most of them work at a pork slicing plant, among them are the two brothers I mentioned above, Ai Mai Peng and Ai Mai Seng, and their two sisters. The two brothers are now both supervisors at the plant.

\section{Marriage}

Marrying within the Tai group is one way for Tai Lue Americans to maintain their traditions, and marriage with other Americans is not common among them. Most Tai Lue Americans migrated to the USA in the 1980s, and most Tai Lue elders had already married in China or Laos, or in the refugee camps in Thailand by that time. In USA, they usually marry someone of the same nationality, mostly Tai Americans, including Tai Neua, whereas a few Tai have married Laotians. Fewer still have married Thais and even fewer have married white or black Americans, or those of other Asian nationalities. One Tai American woman in Connecticut is married to a white man, while one woman in Colorado has a black boyfriend. Some young Tai Lue American men look for a Tai Lue wife in SipsongPanna, and now there are 12 Tai women from SipsongPanna married to Tai American men, having migrated to the USA since 1989.

When it comes to holding the marriage ritual in the USA, it has been impossible for Tai Lue Americans to maintain all of their traditions, but they have retained the core elements of the wedding, including the "tying the thread" ritual and some other traditions. The "tying the thread" ritual is the key part of the wedding ceremony, and represents a holy ritual and the blessing of a permanent marriage. Go-betweens also play an important role in choosing a spouse for Tai Americans in the USA, though partners are free to choose who they marry, when a couple agree to marry, the two sets of relatives will send representatives (usually elders) to discuss the engagement and determine the wedding day, the sum the groom should give to the bride's parents as compensation (for "losing" her) and how much will be spent on the wedding at the bride's parents' home. The engagement sum depends on whether the groom is rich or not, on the local consumption levels and the bride's parents' requirements. However, this sum is usually in the region of \$5,000 in cash and five Bhat (or 75 grams) in gold.

Tai Lue Americans still select the day of the wedding according to the Chulasakaraj Calendar, and if the wedding day is Monday to Friday, the elders will hold the "tying the thread" ritual for the bride and groom on the actual day, and then the wedding celebration will be held at the weekend. Offerings made in addition to the ritual include a pair of boiled, whole chickens (usually young chickens), this being the most important offering. 
At least four or eight elders (50\% male/50\% female) will tie threads for the bride and groom and one of them, usually BorJarn (the head of the lay people's Buddhist activities), will chant a blessing. The bride and groom will then kneel down in front of the offerings and the compere will chant blessings for them for about half an hour. After that, the elders and the bride and groom's parents will respectively tie thread to both the hands of the bride and groom individually, after which all the relatives and friends will celebrate the wedding —eating, drinking and enjoying the entertainment, and giving money to the bride, groom or their parents. I did not have the chance to observe a Tai Lue American wedding, but Khanan Joy and some other informants gave me the above description. Other than holding the wedding at the weekend, the rest of the ceremony is the same as in SipsongPanna, though it is not so easy for friends and relatives to fly or drive from other states to attend the wedding celebrations. One of my informants in San Diego told me that she flew from San Diego to participate in her relative's wedding in Denver, and here, the advanced state of the transportation system in the USA helps them practice their traditions.

\section{Memory and Connecting to Their Homelands}

I regard Tai Lue Americans' relationships and communications with their hometown in SipsongPanna as a form of memory, because on the one hand, SipsongPanna is a space in which they can practice their customs and traditions and, on the other, it is the source of their traditions, which they also support in the USA, as these traditions are not easily displaced by Western culture. Having practiced their traditional culture in the USA and maintained communications with SipsongPanna for nearly 20 years, the places in the USA where the Tai Lue Americans live, as well as SipsongPanna and northern Laos, together form a network of Tai traditional culture, even though this network is not particularly strong or powerful. Many events and traditions happen in SipsongPanna in China, but the participants and the hosts could easily be Tai Lue Americans in the USA. Due to the frequent communications they have with their hometown, traditional events in SipsongPanna respond to and function to support those in the USA, while actions in the USA also act upon their traditional culture in SipsongPanna. The following section supports this point.

\section{Communications With Their Hometown}

Tai Lue Americans maintain close relations and communications with their relatives and friends in SipsongPanna, and in northern Laos. These relations and communications are helpful in order to maintain their traditional activities and behaviors in the USA, and have been facilitated by modern communications and transportation technologies.

Those Tai Americans who are refugees from Laos moved to the USA between 1979 and 1994, but most of them migrated in the 1980s. After they had migrated, they did not immediately return to China, because they still feared China's political movements. Many years later, when they heard China was safe and it was convenient for the overseas Chinese to go back there, some of them began going back to visit their relatives in SipsongPanna. Nang Keo in San Diego told me she was the first Tai American to visit relatives in SipsongPanna in 1988. Nang Keo really missed her young brother at this time, because she had not seen him for over 20 years. When she escaped to Laos, their parents had already died and so she gave her six year-old younger brother to her uncle, for him to raise. She regretted doing that, so was the first person to venture back 
to China. After her trip, once she returned to the USA and told other Tai Lue Americans about the situation in SipsongPanna and China, many of them started to go back to visit their relatives. Recently, due to improvements in transportation, trips to SipsongPanna have become more frequent, and the Tai Lue usually visit SipsongPanna during the Tai New Year Festival celebrations in mid-April.

Advanced telecommunications technology has also provided Tai Lue Americans with a quick and convenient way to contact their relatives in SipsongPanna, and many international telephone companies sell very cheap telephone cards, such as Phone Card Smile, Phone Cheap Card Pins and China One. In 2003, some telephone companies sold telephone cards at $\$ 10$ for 60 hours of calls, and in January 2008, I saw a Tai Lue American in Connecticut buying an international telephone card for just $\$ 2$, which gave 60 hours worth of calls to China. Mobile and landline phones are becoming increasingly common in SipsongPanna, but calling from SipsongPanna is still quite expensive, so usually Tai Lue Americans call their relatives in SipsongPanna; they can do this very often and sometimes will talk for hours at a time.

Banking services also help Tai Lue Americans maintain a link with their relatives in SipsongPanna, and they often remit money to their relatives in order to help them cover their daily expenditure, for rebuilding temples and in support of Buddhist activities. Post services are also helpful, and so often the Tai Lue mail US products to their relatives in China, while their relatives mail them Tai foods in return, which cannot be bought in American markets and can be imported to the USA.

It is very easy for Tai Americans to get a Chinese visa and visit their relatives in SipsongPanna, however, it is not easy for their relatives in SipsongPanna to get a US visa, as their "conditions" do not fulfill the requirements of the US consulate in China. For example, the USA requires them to show their housing address, income and bank deposit certificates when they apply for a visa, but they usually do not have these certificates. Most of the Tai Lue in SipsongPanna are peasants, as are the Tai Lue Americans' relatives. Every Tai family has a house in SipsongPanna, but China's policy is not to issue housing certificates to peasants who live in the countryside. In addition to this, the Tai peasants receive no salary, and no local government can issue a certificate showing their income. As a result, they are unable to meet the conditions set by the US government, due to Chinese government policies. Bor Noor Kham and his wife applied for a US visa in 2003, but were denied because they did not have a housing certificate. Ee Seng got married and migrated to the USA in 1989, after which her parents hoped to visit her, applying for a US visa three times, but each application failed. Her mother then died in November 2006. Ee En and Ee Khan both failed when they applied for a US visa in 2005, and many of my informants told me that only one Tai Lue elder in Muang La County, who is in his eighties, got a US visa, and so visited his relatives in Colorado several years ago. He stayed in Colorado for 11 months and then returned to SipsongPanna.

\section{Marrying Lue Women from SipsongPanna}

As I mentioned in the section on marriage, Tai Lue Americans usually marry among themselves, but sometimes, due to the limited choice in the USA, young Tai American men go back to SipsongPanna in search of a wife, and this activity has been on the increase recently. I was told of one woman who had already got a US fiancé's visa, and that the wedding would be held in SipsongPanna and that after the wedding, she would move to the USA. It is interesting to note that Tai Lue American woman do not marry Tai Lue men in 
SipsongPanna, and I could not discern a clear reason for this. Those Tai women who get married to men from the USA tend to be from the countryside, and do not have a high school education. Also, they usually cannot speak English, though I met one who had graduated from the Teacher Training College of SipsongPanna and another who had finished high school. However, most have only been to the primary schools in their villages. One common trait among them is that they are used to working hard and have a good experience and knowledge of Tai Lue traditional culture and customs. After they move to the USA, they need to learn English for several months before finding a job, as finding a job does not always require them to have a high standard of English. It usually takes several years to get a US fiancé's visa - around two or three years, though I heard of one woman for whom it took eight years to get a visa, since she and her boyfriend were only engaged. One woman I met is still waiting for a US fiancé's visa having been trying for five years, because her Tai Lue American fiancé lost his job and went on the dole. However, when I spoke to her he was working again, so she was going to apply again soon.

\section{Donations to Help Rebuild Temples at Home}

Tai Lue Americans have played an important role in the Buddhist recovery of SipsongPanna. Since the 1980s, they have donated a lot of money towards rebuilding and repairing temples which were destroyed during the Cultural Revolution. Due to a lack of funds, these temples were not well restored and needed to be repaired and rebuilt. Since the 1990s, Tai Lue Americans have had more opportunities to go back to SipsongPanna and donate towards rebuilding temples in their or their relatives' villages. For example, when I carried out my fieldwork in SipsongPanna, I came across many Buddhist temples which Tai Lue Americans had helped rebuild. The following temples offer several examples.

The reconstruction of Wat Ban Dup Temple in Muang Ham was based upon a donation given by Tai Lue Americans. In 1993, Ai Nuon and Por Tao Ham, two families in the USA, donated \$1,000 towards painting gold stencils on the columns and the ceiling of the temple's Buddha hall. By 1998, nine Tai Lue American families whose relatives live in Muang Ham had donated towards building a stupa in the temple yard, sending money directly to the monks at the temple. In early 1999, the construction of this stupa was completed, so the Tai Lue Americans went to attend the unveiling celebration which I was able to attend also. In addition, Ai Noun's family was able to donate towards constructing a well house and a rest hall for the village, and later, they again donated towards building the monks' dormitory.

Wat Ban Long Temple in MuangPoom, Muang La County, was rebuilt between 2003 and 2004 at a total cost of RMB 320,000 (about \$37,600), \$10,500 of which was donated by 12 Tai Lue American families. Among them, Ai Oon's family donated the most: RMB70,000 (about \$8,200), as Ai Oon grew up in the village and his parents never left. In November 2005, the Aye Oon family again donated towards building an ordination hall at the temple, however, most of the money for this work came from Buddhist activities held by Tai Lue Americans. For example, Ee Seng's family twice held a ritual for the offering of Buddhist texts, in 2004 and 2005.

Ban Kieng Village in Muang Yoon, Muang La County, is close to the border with Laos. Many of the villagers from there fled to Laos during the Great Leap Forward and Cultural Revolution periods. As a result, many Tai Lue Americans were born in this village, and they recently asked other Tai Lue Americans to donate towards rebuilding the temple there. In the end, a total of 72 Tai Lue American families donated RMB54,531 
(about $\$ 6,800$ ) to rebuild the Buddha hall between 2005 and 2006, individually donating between RMB16 (about \$2) and RMB20,000 (\$2,500). Added to this, Ee Dan donated towards the cost of building three gates leading to the Buddha hall, while other Tai Lue Americans met the bill for building two dragon and four lion statues beside the two main gates. In fact, most of the income for the temple's reconstruction came from the rituals held by Tai Lue Americans.

In total, 25 Tai Lue American families donated more than RMB200,000 towards rebuilding Wat Ban Khai Temple in Meng Long during the 1990s, helping to rebuild the Buddha hall, the monk's dorm, the drum tower and a Buddha image in the Buddha hall.

\section{Sponsoring Monk Ordinations}

Tai American elders are also maintaining the tradition of sponsoring monks and novice ordination rituals. One of the beliefs held by Theravada Buddhists is that people will receive a great deal of merit if they send their son to be a novice and/or a monk, and take responsibility for their ordination ceremony. As a result, sponsoring monk ordinations is popular among Tai Lue Americans, and a small number of Tai Lue American boys have also been ordained as monks and novices themselves. Many Tai Lue American elders use their annuities or retirement pensions to cover the expenditure on monk and novice ordination celebrations in SipsongPanna and northern Laos, and for those in the USA, an ordination ceremony does not cost so much at just a few hundred US Dollars.

Khanan La (a former monk) from Colorado, was born in Ban Sue Village, Meng Long in SipsongPanna, but escaped to Myanmar in 1958 before entering Laos. He went back to SipsongPanna three times and sponsored monk and novice ordinations each time. Mai Dan was born in Ban Chiang Rae Village in Muang Sing, Laos in 1934, but his parents were Tai people from Meng Long in SipsongPanna. His parents migrated to Muang Sing two months before he was born, so Mai Dan still has many relatives in Meng Long, and he has sponsored monk and novice ordinations four times since the 1990s; once for two novices in Ban Chiang Rae

Village in Muang Sing and three times in SipsongPanna, one monk and four novice ordinations in Ban Haye Village, one monk ordination in Ban Na Long Village, and one monk ordination in Ban Nam Kham Village, Meng Long.

\section{Conclusion}

Historical, political movements and wars forced the Tai Lue to leave their home towns in SipsongPanna, China, and many of them having little choice but to migrate to the USA. There are many sad stories of their escape from SipsongPanna in China to Laos and then Thailand, and sometimes I could not help feeling quite emotional when I listened to their stories during my field work. Some elders still look forward to going back home to live in SipsongPanna, as they told me they are rich in terms of health, food and products in America but that they still feel lonely inside their hearts. They like SipsongPanna, a place where they can see relatives, friends and neighbors at all times. Also, there are many festivals held in SipsongPanna for them to participate in. However, they worry that China's policies may change towards them; harming them again, so in terms of yearning for their hometown, practicing their traditions prevents them from becoming too homesick.

However, Tai Lue traditional culture and customs are being modified in the USA, but have not been displaced entirely by American culture. The Tai Lue have had both positive and negative experiences in the USA, negotiating with the mainstream culture and modifying their behaviors in order to maintain their 
traditions. For example, the work skills required, working environments and working times are all different from what they were used to in Asia. However, the cultural freedom the USA offers has provided them with the space to maintain their traditional culture, though some aspects conflict with American laws and regulations. As a result, American and Western culture have also influenced their traditions.

Possibilities and similarities have created a space for Tai Lue American traditional culture to survive, and the conditions and environments present in the USA have allowed Tai Lue Americans to practice and maintain their culture and customs. In most cases, they have been able to find something similar to their own culture in the American environment; to support their memories and their traditional habits, and this has made them feel relatively comfortable there. They do not want to abandon their traditions entirely and adopt new ones, as this would make them uncomfortable, and most of their traditions, habits, rituals and behaviors can still be maintained in the USA. For example, they have not had to stop practicing Theravada Buddhism or their other traditional rituals. Buddhist temples have always been at the center of their activities and communications, even when they escaped from China to Laos and then to Thailand. When their religions and traditions were destroyed during China's Great Leap Forward and Cultural Revolution periods, they fled to Laos or Burma where they could still perform their religious activities and traditions, along with the local Tai people. For example, they built a Buddhist temple in the refugee camp at Chiang Kham in northern Thailand, and were still able to perform their Buddhist activities there. After migrating to the USA, they built their own temples and continued their traditional behaviors, and this helped them maintain their traditions.

Globalization has also allowed the Tai Lue Americans to maintain their culture and traditions in the USA; for example, the global circulation of goods has made it possible for migrants to choose to buy what they need, and technological changes such as the internet, media, telecommunications and transportation have made it possible for Tai Lue Americans to source, choose and consume similar products to those found in China. Therefore, with globalization, Tai Lue traditional culture has become available to Tai Lue Americans, allowing their traditions to survive.

Lao Americans and Thai Americans, whose cultures are similar to Tai Lue culture, have a larger population base in the USA, thus, they have a greater ability to preserve their cultures there. As a result, they have been able to provide Tai Lue Americans with a reference point, and with resources that the Tai Lue Americans can rely on, learn from and imitate, though they themselves are assimilating Tai Lue American traditions.

Tai Lue Americans are still moving around the USA, as they can move easily from one state to another, like all US citizens. When I visited San Diego in February and March 2003, there were 56 Tai Lue American families living there, but by August 2007, during my second visit, I was told that only 11 Tai Lue American families remained. The main reason for this is that house prices were rising in San Diego and finding a job at that time was becoming harder. As a result, most families had sold their expensive houses in San Diego and moved to other states where houses were larger and cheaper, and where finding a job was easier. However, nobody was returning to SipsongPanna in China.

I cannot be certain of what the future holds for Tai Lue Americans, as there are only a small number of Tai monks in the USA, and they are the protectors, advocates and educators of Tai Lue traditional culture. As a result, Tai Lue Americans have less time to perform their traditions then those living in China, due to some traditions conflict with US society and laws. In addition, Tai Lue culture in SipsongPanna is also being assimilated by Han Chinese culture, and this may further reduce the level of support provided to Tai Americans 
and their traditions. As a result, it will be hard for Tai Lue American elders to transfer their traditions to the future generations, and no culture can exist forever. However, I hope that Tai Lue traditional culture will live on and that Tai Lue Americans continue to experience happiness and contentment in the USA, and that they can share this happiness with others.

\section{Reference}

CHU, L., \& Tien, C. Y. (1974). Inside a people's commune-Report from Chiliying. Beijing: Foreign Language Press.

GAO, L. S. (1992). Xishuangbann Li Shi Yu Wen Hua (Xishuangbanna history and culture). Kunming: Yunnan Nationalities Press.

Hamilton-Merritt, J. (1993). Tragic mountains: The Hmong, the Americans, and the secret wars for Laos, $1942-1992$. Bloomington and Indiana-polis: Indiana University Press.

Kirshenblatt-Gimblett, B. (1998). Destination culture: Tourism, museum, and heritage. California: University of California Press. ZHENG, P. (2003). Cong Ling Zhu Dao Gong Pu (From a Seignior to a Public Servant). Kunming: Yunnan Art Press. 